\title{
SNP-based method for the genetic identification of ramin Gonystylus spp. timber and products: applied research meeting CITES enforcement needs
}

\author{
Rob Ogden ${ }^{1,5, *}$, H. Noel McGough ${ }^{2}$, Robyn S. Cowan ${ }^{2}$, Lilian Chua ${ }^{3}$, \\ Madeleine Groves ${ }^{2}$, Ross McEwing ${ }^{4,5}$ \\ ${ }^{1}$ Wildlife DNA Services, Tepnel, Appleton Parkway, Livingston EH54 7EZ, UK \\ ${ }^{2}$ Royal Botanic Gardens, Kew, Richmond, Surrey TW9 3AB, UK \\ ${ }^{3}$ Forest Research Institute Malaysia (FRIM), 52109 Kepong, Selangor, Malaysia \\ ${ }^{4}$ TRACE Wildlife Forensics Network, Science Campus, Deiniol Rd, Bangor LL57 2UW, UK \\ ${ }^{5}$ School of Biological Sciences, Bangor University, Deiniol Road, Bangor LL57 2UW, UK
}

\begin{abstract}
We describe the development of a genetic assay for the identification of the tropical hardwood ramin Gonystylus spp., a CITES-listed genus subject to illegal international trade. Samples representing different ramin species, confamilial genera and morphologically similar taxa were obtained. DNA extraction from leaf material and wood products was achieved using commercially available kits. Five chloroplast genes were examined for Single Nucleotide Polymorphism (SNP) loci capable of discriminating ramin. A locus within the matK gene was selected and a TaqMan ${ }^{\circledR}$ assay designed for sample genotyping. The assay was validated against different species to demonstrate its specificity and reproducibility. The final assay provides a robust, cost-effective, transferable method for identifying processed ramin. The research represents a feasibility study, addressing each of the steps required to develop a genetic identification assay for enforcement use; however, it should be noted that further work is required to produce a fully validated forensic identification tool.
\end{abstract}

KEY WORDS: Illegal trade $\cdot$ Logging $\cdot$ Forensics $\cdot$ Endangered species $\cdot$ Species identification

\section{INTRODUCTION}

The illegal international trade in flora and fauna leads to loss of habitat and biodiversity on a global scale, as well as sustaining organised crime. Despite increasing efforts to implement trade regulations, fundamental issues such as the species identification of traded products continue to hamper law enforcement. In cases where external anatomical characteristics have been lost, forensic DNA techniques are now being used to identify items being smuggled or sold illegally. Genetic identification of species has been applied to a number of Convention on International
Trade in Endangered Species (CITES) enforcement issues, including illegal fishing (Magnussen et al. 2007), the ivory trade (Wasser et al. 2004) and trade in traditional Asian medicines (Linacre et al. 2003). Applications to timber identification have long been recognised but until recently such approaches have been restricted by technical limitations. Advances in DNA recovery (Deguilloux et al. 2002, Asif \& Cannon 2005), coupled with the increase in availability of genomic sequence data through initiatives such as the Barcoding of Life (Chase et al. 2007, Hollingsworth 2008), have now paved the way for the development of forensic genetic timber-identification methods. 
The current method for the identification of traded timber and processed wood products is anatomical analysis. Identification of single samples can be performed quickly and reliably by expert wood anatomists, and the technique is routinely employed at specialist research institutes in several countries, including the UK, the USA and Germany. The recent development of a computer-based anatomical key (Richter et al. 2008) has also improved the potential for initial identification of many traded timber species by enforcement officials. Despite these resources, identification of certain species remains problematic; with a growing need to routinely screen large numbers of samples, a complementary technique is required. The development of a DNA-based technique, employed as a standard laboratory tool, capable of high throughput analysis and of delivering categorical identification for forensic application would enhance the ability of both commercial and government authorities to regulate the trade. Where necessary, such techniques would also support the enforcement of national and international legislation, allowing exporting and importing countries to identify and prosecute illegal movements, greatly increasing our chances of ensuring a sustainable trade in timber.

Ramin Gonystylus spp. is a light tropical hardwood tree of swamp forests with a centre of diversity in the island of Borneo (Tawan 2004). The distribution includes Brunei Darussalam, Fiji, India (Nicobar Islands), Indonesia (Kalimantan and Sumatra), Malaysia (Peninsular Malaysia, Sabah, Sarawak), Papua New Guinea, the Philippines and the Solomon Islands (T. M. A. Utteridge pers. comm.). The Gonystylus genus includes about 30 species (Tawan 2004), although a full taxonomic review to confirm the exact status of described species is currently required (T. M. A. Utteridge pers. comm.). Of these species some 10 taxa are reported to have uses as timber or medicine (some taxa produce Agar) (CITES 2002). A number of species have been reported in international trade, with $G$. bancanus supplying, by far, the greater part of the market. Lim et al. (2004) estimated the annual trade in ramin to be worth more than US $\$ 100$ million $\mathrm{yr}^{-1}$. A proposal submitted by Indonesia to list the genus Gonystylus on Appendix 2 of CITES was adopted by consensus at the 13th meeting of the CITES Conference of the Parties in Bangkok, Thailand in October 2004 (Gray 2005). The generic listing was proposed to allow adequate identification using traditional wood anatomy techniques. All parts and derivatives of ramin wood were subject to CITES regulation to match the international market.

The European Union (EU) is a major importer of ramin, as is the USA. Within the EU, Italy imports the largest portion of ramin; other major importers include the UK, the Netherlands, Germany, Belgium, and Spain (Affre et al. 2004). Due to its high market value, ramin is subject to illegal trade into and within the EU, often in the form of finished products (Fig. 1) that are difficult or too numerous to identify anatomically. The EU also re-exports ramin products, such as dowels, picture frames and paint brushes. The trade is dominated and hence characterised by the movement of large numbers of finished products. It was the first trade of this type to be subject to CITES control (Affre et al. 2004).

We present here the research and development undertaken to produce a validated method for the forensic genetic identification of ramin Gonystylus spp. timber and wood products for use by enforcement agencies (customs/border inspection), and traders of timber and wood products. The project was designed as a pilot study to provide proof of concept for the development of an applied assay. It therefore had a limited scope, targeting a single genus, but including all stages in the production of an assay, from sample collection and DNA extraction through to marker selection, assay design and validation. Importantly, the research was driven by the needs of the end user, in this case, Her Majesty's (HM) Revenue and Customs (UK). This approach led to criteria governing the assay being specified from the outset, including considerations of assay transferability, per-sample cost, sample capacity, speed of assay and robustness of the technique to provide reliable evidence for legal prosecution.
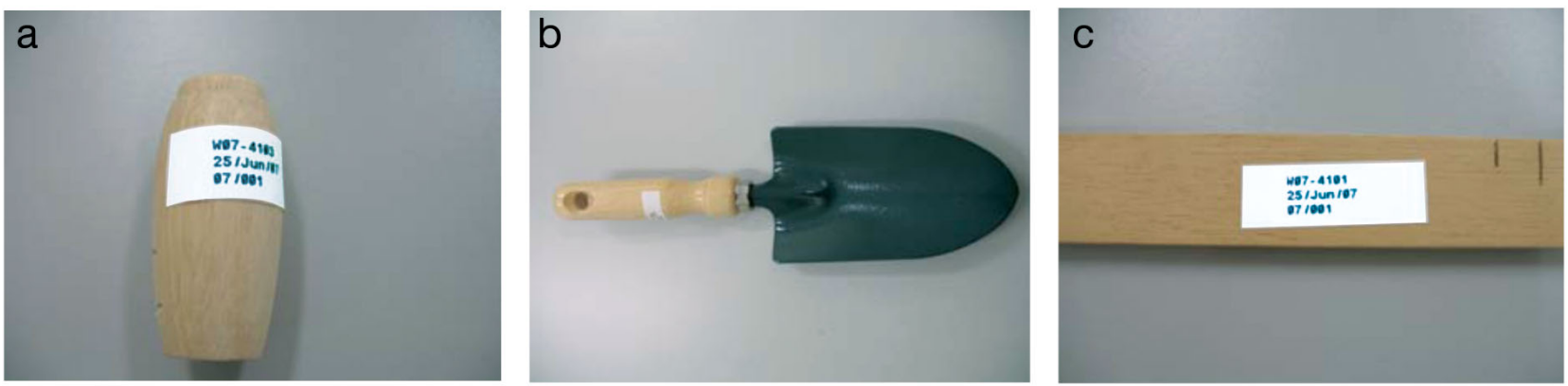

Fig. 1. Examples of previously identified processed ramin timber products: (a) window blind toggle; (b) garden trowel handle; (c) panel of window blind 


\section{MATERIALS AND METHODS}

Sample collection. Ramin: Authenticated samples were obtained for 7 species of ramin including all of those commonly traded. Leaf tissue was obtained from the Forest Research Institute of Malaysia under CITES licence. Wood samples were provided from the collection at Royal Botanical Gardens (RBG) Kew. In addition, a number of samples of processed wood products were donated by HM Revenue and Customs CITES team. These had been stored following seizure and had been identified anatomically by wood anatomists at RBG Kew as originating from ramin species.

Genetically similar taxa: The genus Gonystylus, belongs to the family Thymeleaceae, subfamily Gonystyloideae, which also includes the genera Solmsia, Arnhemia and Lethedon (Van der Bank et al. 2002). Representatives of each genus (S. calophylla, A. cryptantha and L. cernua) were obtained from the DNA bank at RBG Kew to compare with Gonystylus spp. at the same genetic marker.

Anatomically similar taxa: A total of 17 additional species were selected for validation of the ramin identification assay on the basis that their timber and or processed products may be confused with ramin during anatomical analysis. All samples were donated by the Economic Botany Collection at RBG Kew.

DNA extraction. DNA extraction was initially attempted on freshly dried leaf tissue, followed by timber samples and finally worked wood products in a dedicated (PCR-free) laboratory. Extraction was performed directly on leaf tissue. Wood material was prepared by initially sanding samples to remove the outer wood layer where chemical deposits and exogenous DNA contamination would likely be present. Sub-samples of wood were then taken using a hacksaw, sterilised between samples. Extraction controls were carried through to PCR amplification.

Two commercial kits designed for plant material were used, the Nucleon Phytopure ${ }^{\circledR}$ kit (Tepnel Life Sciences) based on a simple salt extraction method and the GMO BioKit ${ }^{\circledR}$ (Tepnel Biosystems) based on magnetic bead DNA capture. Manufacturer's protocols were followed throughout.

The quality of DNA recovered from both the leaf and processed timber was assessed through PCR amplification. The DNA recovered from processed wood was expected to be of inferior quality (reduced yield and fragmented) compared to fresh leaf material. The extent of the fragmentation was assessed using PCR amplification of 2 different sequence length products. The first fragment was an $800 \mathrm{bp}$ fragment from the chloroplast matK gene amplified using the universal primers developed for this purpose; the second fragment was a $300 \mathrm{bp}$ product (more than the product length required for the final DNA test) from the same gene using specifically designed primers based on ramin DNA sequences. The primer sequences are as follows: Large Fragment Forward Primer (LFFP), CCTATCCATCTGGAAATCTTAG (matk2.1); LF reverse P, GTTCTAGCACAAGAAAGTCG (matk5); Small FFP (SFFP), CGTGTGGTCTCAATCAGGAA (matk415f); SFRP, CGATGCGTTACAAAAATTCG (matk637r). PCR reaction conditions were: $20 \mu \mathrm{l}$ reaction containing 0.25 units ABgene Thermo-Start DNA Polymerase, $1 \times$ Thermo-Start $^{\circledR}$ reaction buffer, $2.5 \mathrm{mM}$ $\mathrm{MgCl}_{2}, 0.2 \mathrm{mM}$ each dNTP, 20 pmol primer and $2.0 \mu \mathrm{l}$ of template DNA. PCR was performed on a PTC-200 MJ Research thermocycler under the following parameters: $95^{\circ} \mathrm{C}$ for $15 \mathrm{~min} ; 40$ cycles of $94^{\circ} \mathrm{C}$ for $60 \mathrm{~s}, 48^{\circ} \mathrm{C}$ for $60 \mathrm{~s}, 72^{\circ} \mathrm{C}$ for $60 \mathrm{~s}$; followed by $72^{\circ} \mathrm{C}$ for $5 \mathrm{~min}$. Amplification products were visualised under UV light following electrophoresis on an ethidium bromidestained $2 \%$ agarose gel.

Genetic marker selection. Five candidate partial gene regions present in plastid DNA were selected for investigation as potential discriminatory markers: matK, rpoC1, rpoB, accD and ndhJ. DNA sequences were initially produced for 2 Gonystylus species (G. macrophyllus and G. borneensis) and the 3 confamilial genera to identify inter and intra-genus Single Nucleotide Polymorphisms (SNPs). Following the selection of a single target gene region, the reference samples for the remaining 5 Gonystylus species were sequenced to confirm that SNP genotypes were conserved within the genus. The barcoding primer sequences and PCR reaction conditions used to amplify each region are published at www.kew. org/barcoding/protocols.html. PCR products were cleaned using QIAquick silica columns (Qiagen) and sequenced using Bigdye 3.1 terminator chemistry on an ABI 3730 following manufacturer's protocols (Applied Biosystems). The sequences were aligned to allow identification of SNPs that vary among species. The availability of diagnostic SNPs was then used to select the genetic marker to be targeted during assay development.

Assay design. The SNP genotyping method selected for the assay was a TaqMan ${ }^{\circledR}$ probe (Applied Biosystems). Three candidate SNPs were assessed for their suitability as TaqMan ${ }^{\circledR}$ target loci. Primers and probes were subsequently designed for a single SNP locus using the proprietary software, Primer Express (ABI). The total target sequence was only $95 \mathrm{bp}$ long and consisted of the following primers and probes: primer 1 , 5'-GGAAAATCTATTCTCGCTTCAAAAGA-3'; primer 2, 5'-TTATGGCAATATCATTTTTACGTGTG-3' and probe, 5'-ACGCCTCTTCTrATG-3'. The assay was run under standard TaqMan ${ }^{\circledR}$ PCR conditions on an ABI 7500 machine. In addition to positive ramin and non-ramin 
samples, a mixed sample was created from a 1:1 ratio of ramin and non-ramin DNA and run alongside the test samples and no-template controls (NTCs).

Validation. The resulting $\operatorname{TaqMan}^{\circledR}$ assay was investigated to examine its performance with different tissue types (leaf vs. heart wood), different species (17 lookalike species) and different DNA concentrations. Standardised conditions were employed to assess assay performance. In addition to validation of the assay itself, a positive control was developed to demonstrate the presence of DNA in samples that show no result with the TaqMan ${ }^{\circledR}$ probe, i.e. for species that are highly genetically distinct from ramin. The control consisted of a chloroplast microsatellite locus (CCMP2) approximately twice as long as the TaqMan ${ }^{\circledR}$ target region ( 189 bp), amplified under published conditions (Weising \& Gardener 1999), that amplifies in most angiosperms.

\section{RESULTS}

Sample collection. A full list of the samples obtained is shown in Table 1. These samples were sufficient to develop the assay within the remit of this pilot project. Examples of the processed timber products used are shown in Fig. 1.

DNA extraction. DNA was successfully recovered and PCR-amplified from both fresh plant material and 3 specimens of processed/worked ramin. In all cases, the short (300 bp) region could be amplified; however, the large $(800 \mathrm{bp})$ fragment was only amplified in fresh leaf material, as expected. Both extraction kits enabled amplification of the target loci.

Genetic marker selection. Evaluation of the DNA sequences produced for each of the 5 candidate gene regions indicated that the marker matK contained the highest number of SNPs potentially capable of distinguishing ramin from non-ramin samples (Table 2). Of the 5 SNP positions identified, 3 were conserved across all 7 Gonystylus species; 1 of these was then selected for the design of a TaqMan ${ }^{\circledR}$ assay on the basis of probe stringency. The assay performed as predicted, correctly discriminating ramin from non-ramin samples. Sample identification was definitive in all cases, with distinct clusters formed for both SNP genotypes (Fig. 2). The mixed sample and no-template controls were positioned as expected. To process 24 samples takes approximately $2 \mathrm{~h}$.

Validation. The assay worked with DNA recovered from all sample types tested, including the worked products. Results were obtained at DNA concentrations down to $0.01 \mathrm{ng}^{\mathrm{l}} \mathrm{l}^{-1}$. No false positives were observed across the 20 non-ramin species tested (3 genetically similar and 17 anatomically similar). 'No

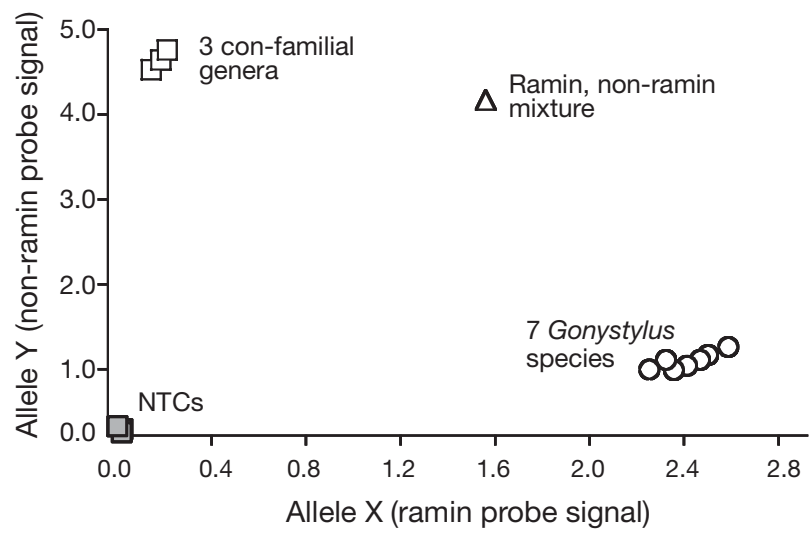

Fig. 2. Results of the TaqMan ${ }^{\circledR}$ assay showing differentiation of the 7 ramin Gonystylus spp. from the 3 genetically related species. The assay is based on allele-specific fluorescent probes that are incorporated during PCR according to the nucleotide base present at the Single Nucleotide Polymorphism (SNP) (1 colour for each allele). The genotype of each sample is then obtained by measuring the fluorescent intensity of the probes. In the ramin assay, the $x$-axis displays the signal from the ramin allele and the $y$-axis the non-ramin allele. Triangle represents a 1:1 DNA mixture control, shaded squares are no-template controls (NTCs)

result' was recorded for all 17 lookalike species; however, 15 of these amplified with the microsatellite control, demonstrating the presence of amplifiable wood DNA.

\section{DISCUSSION}

This study has demonstrated the potential to efficiently combine a series of modern genetic analysis techniques in order to produce a working assay suitable for direct application as an enforcement tool. The ability to genetically discriminate traded ramin from non-ramin wood provides a complementary technique to current anatomical methods. The use of standard commercially available extraction methods and the TaqMan ${ }^{\circledR}$ genotyping platform offers a highthroughput solution that can be applied worldwide with minimal training. It is estimated that 96 samples could be readily processed by 1 person in a single day, dramatically reducing time costs relative to current methods. This in turn will facilitate larger scale trade monitoring and survey effort, providing the tools required to adequately enforce the CITES listing and deter the illegal movement of ramin.

The scope of the work undertaken was limited to a proof of concept model, and further work is planned to increase the utility of the assay produced. Heavily processed wood products, such as heat-treated plywood, need to be tested to examine the performance of the 
Table 1. All samples provided for the project, showing type, provider and geographic origin of samples. HMRC: Her Majesty's Revenue and Customs CITES Team; FRIM: Forest Research Institute of Malaysia; RBGK: Royal Botanic Gardens, Kew

\begin{tabular}{|c|c|c|c|}
\hline $\begin{array}{c}\text { Category } \\
\text { Species }\end{array}$ & $\begin{array}{l}\text { Sample } \\
\text { type }\end{array}$ & $\begin{array}{l}\text { Sample } \\
\text { provider }\end{array}$ & $\begin{array}{l}\text { Geographic } \\
\text { provenance }\end{array}$ \\
\hline \multicolumn{4}{|l|}{ Ramin-reference sample } \\
\hline Gonystylus maingayi & Leaf & FRIM & Malaysia \\
\hline Gonystylus bancanus & Leaf & FRIM & Malaysia \\
\hline Gonystylus affinis & Leaf & FRIM & Malaysia \\
\hline Gonystylus confusus & Leaf & FRIM & Malaysia \\
\hline Gonystylus brunnescens & Leaf & FRIM & Malaysia \\
\hline Gonystylus macrophyllus & DNA & RBGK & Indonesia \\
\hline Gonystylus borneensis & DNA & RBGK & Brunei \\
\hline \multicolumn{4}{|l|}{ Ramin — case sample } \\
\hline Gonystylus spp. & Worked timber & HMRC & Unknown \\
\hline Gonystylus spp. & Worked timber & HMRC & Unknown \\
\hline Gonystylus spp. & Worked timber & HMRC & Unknown \\
\hline \multicolumn{4}{|l|}{ Genetically similar } \\
\hline Solmsia calophylla & DNA & RBGK & Australia \\
\hline Arnhemia cryptantha & DNA & RBGK & Unknown \\
\hline Lethedon cernua & DNA & RBGK & New Caledonia \\
\hline \multicolumn{4}{|l|}{ Morphologically similar } \\
\hline Alstonia macrophylla & Wood & RBGK & Malaysia \\
\hline Alstonia macrophylla & Wood & RBGK & Sri Lanka \\
\hline Alstonia scholans & Wood & RBGK & Sri Lanka \\
\hline Alstonia scholans & Wood & RBGK & Malaysia \\
\hline Anthocephalus cadamba & Wood & RBGK & Western New Guinea \\
\hline Anthocephalus cadamba & Wood & RBGK & Malaysia \\
\hline Anthocephalus monandaefolius & Wood & RBGK & India \\
\hline Brosimum alicastrum & Wood & RBGK & Mexico \\
\hline Brosimum alicastrum & Wood & RBGK & Trinidad \\
\hline Brosimum alicastrum & Wood & RBGK & Jamaica \\
\hline Brosimum alicastrum & Wood & RBGK & USA \\
\hline Brosimum paraense & Wood & RBGK & USA \\
\hline Dyera costulata & Wood & RBGK & Malaysia \\
\hline Dyera costulata & Wood & RBGK & Malaysia \\
\hline Dyera costulata & Wood & RBGK & North Borneo \\
\hline Intsia baken & Wood & RBGK & Malaysia \\
\hline Instia bijuga & Wood & RBGK & North Borneo \\
\hline Instia palembanica & Wood & RBGK & Malaysia \\
\hline Jacaranda copaia & Wood & RBGK & Panama \\
\hline Jacaranda copaia & Wood & RBGK & Guyana \\
\hline Jacaranda copaia & Wood & RBGK & Unknown \\
\hline Jacaranda copaia & Wood & RBGK & Surinam \\
\hline Jacaranda copaia & Wood & RBGK & Guyana \\
\hline Jacaranda copaia & Wood & RBGK & Unknown \\
\hline Jacaranda copaia & Wood & RBGK & Surinam \\
\hline Jacaranda copaia & Wood & RBGK & Unknown \\
\hline Quassia amara & DNA & RBGK & Unknown \\
\hline Shorea accuminata & Wood & RBGK & Malaysia \\
\hline Shorea leprosula & Wood & RBGK & Malaysia \\
\hline Shorea panvistipulata & Wood & RBGK & Sarawak \\
\hline Shorea platyclados & Wood & RBGK & Malaysia \\
\hline Shorea platyclados & Wood & RBGK & North Borneo \\
\hline Simaruba amara & Wood & RBGK & Guyana \\
\hline Simaruba amara & Wood & RBGK & Trinidad and Tobago \\
\hline Simaruba amara & Wood & RBGK & Brazil \\
\hline
\end{tabular}

assay on a wider range of case-type samples. Further, genetically related and anatomically similar taxa should also be tested, focussing on more species within the con-familial genera and additional Gonystylus species sampled from a broader geographic range. The use of a single SNP to identify ramin demonstrates the strength of the technique, but the inclusion of further SNPs showing the same diagnostic pattern would increase confidence in the assay without impacting heavily on practical implementation.

The development of this assay builds on recent research seeking to apply molecular genetic tech- 
Table 2. Detail of the variable nucleotide positions observed at each of the 5 genes for 5 reference samples. Numbers shown are base pairs from the start of the consensus gene sequence for all 5 species. Gene sequence lengths were $300 \mathrm{bp}(\mathrm{accD}), 737 \mathrm{bp}$ (matK), $432 \mathrm{bp}(n d h J), 426 \mathrm{bp}(r p o B)$ and $619 \mathrm{bp}($ rpoC). GenBank accession nos. are given in the same order as the genes in the previous columns. Potential ramin diagnostic Single Nucleotide Polymorphisms (SNPs) are identified by an asterisk

\begin{tabular}{|c|c|c|c|c|c|c|}
\hline \multirow[t]{5}{*}{ Species } & \multicolumn{5}{|c|}{ Variable positions at each locus } & \multirow{5}{*}{$\begin{array}{c}\text { GenBank } \\
\text { Accession Nos. }\end{array}$} \\
\hline & $a c c D$ & matK & $n d h J$ & $r p o B$ & rpoC1 & \\
\hline & 22 & 11112222334455556666667 & 1 & 1112223 & 11122233 & \\
\hline & 44 & 401692237166602661344793 & 78 & 682562598 & 17906959 & \\
\hline & 09 & 166881659940760128408711 & 66 & 695639271 & 11877256 & \\
\hline Gonystylus macrophyllus & TG & GCCACTCAAAAACTGGGCAGTTCC & GT & TCATGCCTC & TCGATACA & $\begin{array}{l}\text { FJ379770, FJ379775, FJ379780 } \\
\text { FJ379785, FJ379792 }\end{array}$ \\
\hline Gonystylus borneensis & TG & GCCACTCAAAAACTGGGCAATTCC & GT & TCATGCCTC & TCGATCCA & $\begin{array}{l}\text { FJ379774, FJ379779, FJ379784 } \\
\text { FJ379789, FJ379794 }\end{array}$ \\
\hline Solmsia calophylla & $\mathrm{TA}$ & AACAATCGAAGATCGAGCAGTGCT & $\mathrm{CC}$ & CTATGCCTT & CYRAYMGA & $\begin{array}{l}\text { FJ379771, FJ379776, FJ379781 } \\
\text { FJ379786, FJ379790 }\end{array}$ \\
\hline Arnhemia cryptantha & TA & GATGCCTGCAGCTCTATGCGTGTC & GC & CTTCAATGT & CTGGCCGA & $\begin{array}{l}\text { FJ379772, FJ379777, FJ379782 } \\
\text { FJ379787, FJ379791 }\end{array}$ \\
\hline Lethedon cernua & GG & GACACTCAACGACCGAGCAGCGCC & GC & СтATGCCTC & CCAATCGC & $\begin{array}{l}\text { FJ379773, FJ379778, FJ379783 } \\
\text { FJ379788, FJ379793 }\end{array}$ \\
\hline Ramin discriminatory SNPs & & $\star * \star *$ & * & ** & * & \\
\hline
\end{tabular}

niques to plant identification for trade control. Several publications have described the use of short fragment-length sequencing as an effective method for analysing degraded DNA (Deguilloux et al. 2004, Ziegenhagen et al. 2005, CITES 2006) and the use of real-time PCR has also been highlighted (Gugerli et al. 2005). The current study draws together many methodological advances within a forensic framework and suggests how the future application of genetic research to trade enforcement can be achieved.

In the broader enforcement context, the use of forensic genetic techniques for timber identification can be seen as complementary to existing anatomical identification techniques. With the development of new genetic assays, work should also be undertaken to develop an integrated approach to timber identification that can be implemented on a global scale, providing a suite of tools for enforcement officers.

Acknowledgements. The authors gratefully acknowledge the following for their assistance in data generation, sample provision and technical advice, respectively: L. Kelly and P. Gasson (RBG Kew, UK), and O. Gailing (Institute of Forest Genetics and Forest Tree Breeding, University of Goettingen, Germany). The work was funded by the Department for Environment, Food and Rural Affairs - the UK CITES Management Authority.

\section{LITERATURE CITED}

Affre A, Kathe W, Raymakers C (2004) Looking under the veneer. Implementation manual on EU timber trade control: focus on CITES-listed trees. Report to the European Commission. TRAFFIC Europe, Brussels

Asif MJ, Cannon CH (2005) DNA extraction from processed wood: a case study for the identification of an endangered timber species (Gonystylus bancanus). Plant Mol Biol Rep 23:185-192

Chase MW, Cowan RS, Hollingsworth PM, van den Berg C and others (2007) A proposal for a standardized protocol to barcode all land plants. Taxon 56:295-299

CITES (Convention on International Trade in Endangered Species) (2002) Identification manual Vol. 1 Flora. Gonystylus spp. CITES Secretariat, Geneva

CITES (2006) Development of a molecular method to rapidly identify species of the genus Galanthus (Amaryllidaceae, CITES Appendix II). A report by the German CITES Scientific Authority. No. PC16 Inf. 10. www.cites.org/ common/com/PC/16/X-PC16-10-inf.pdf

Deguilloux MF, Pemonge MH, Petit RJ (2002) Novel perspectives in wood certification and forensics: dry wood as a source of chloroplast, mitochondrial and nuclear DNA. Proc R Soc Lond B Biol Sci 269:1039-1046

> Deguilloux MF, Pemonge MH, Petit RJ (2004) DNA-based control of oak wood geographic origin in the context of the cooperage industry. Ann For Sci 61:97-104

Gray J (2005) The 13th Meeting of the Conference of the Parties to CITES. TRAFFIC Bulletin 20(2): 57-70

Gugerli F, Parducci L, Petit RJ (2005) Ancient plant DNA: review and prospects. New Phytol 166:409-418

> Hollingsworth PM (2008) DNA barcoding plants in biodiversity hotspots: progress and outstanding questions. Heredity $101: 1-2$

Lim TW, Soehartono T, Chen HK (2004) Framing the picture: an assessment of ramin trade in Indonesia, Malaysia and Singapore. TRAFFIC Southeast Asia, Selangor

> Linacre A, Hsieh HM, Huang LH, Tsai LC, Kuo YC, Meng $\mathrm{HH}$, Lee JCI (2003) Identification of rhino from medicinal powders and sculptures. Forensic Sci Int 131:1-11

Magnussen JE, Pikitch EK, Clarke SC, Nicholson C, Hoelzel AR, Shivji M (2007) Genetic tracking of basking shark products in international trade. Online Early Publications, Animal Conservation 10(2):199-207

Richter HG, Gembruch K, Koch G (2008) Software program: CITESwoodID version 1.0. BFH German Federal Agency for Nature Conservation, Berlin 
Tawan CS (2004) Thymelaeaceae. In: Soepadmo E, Saw LG, Chung RCK (eds) Tree flora of Sabah and Sarawak, Vol 5, p 433-484. Forest Research Institute Malaysia, Kuala Lumpur

Van der Bank M, Fay MF, Chase MW (2002) Molecular phylogenetics of Thymeleaceae with particular reference to African and Australian genera. Taxon 51:329-339

Wasser SK, Shedlock AM, Komstock K, Ostrander EA, Mutayoba B, Stephens M (2004) Assigning African elephant

Editorial responsibility: Brendan Godley,

University of Exeter, Cornwall Campus, UK
DNA to geographic region of origin: applications to the ivory trade. Proc Natl Acad Sci USA 101:14847-14852

Weising K, Gardener RC (1999) A set of conserved PCR primers for the analysis of simple sequence repeat polymorphisms in chloroplast genomes of dicotyledonous angiosperms. Genome 42:9-19

Ziegenhagen B, Fady B, Kuhlenkamp F, Liepelt S (2005) Differentiating groups of Abies species with a simple molecular marker. Silvae Genet 54:123-126

Submitted: August 20, 2008; Accepted: September 5, 2008 Proofs received from author(s): October 31, 2008 